\title{
ASSESSMENT OF THE RELATIONSHIP BETWEEN ENTREPRENEURIAL ORIENTATION, ORGANISATIONAL CULTURE ADAPTABILITY AND PERFORMANCE OF CHRISTIAN FAITH-BASED HOTELS IN KENYA
}

\author{
Ruth Wanjiku Muriithi \\ School of Business, Karatina University \\ Karatina, Kenya \\ muriithiwaruth@gmail.com \\ Teresia Kyalo \\ School of Business, Karatina University \\ Karatina, Kenya \\ teresakyalo@gmail.com \\ Josphat Kinyanjui \\ School of Pure and Applied Science, Karatina University \\ Karatina, Kenya \\ jkinyanjui@karu.ac.ke
}

\begin{abstract}
Organisational culture has been the focus in both theory and practice and has captured attention throughout the last decade because of its substantial relationship between the concept itself and its outcomes such as gaining competitive advantage and performance in businesses. Entrepreneurial Orientation refers to the strategy making processes that it provides organisations with a basis for entrepreneurial decisions and actions. Despite of its importance and being a popular entrepreneurship concept there is little evidence of research that has been done to determine the relationship between Entrepreneurial Orientation, organisational culture adaptability and performance in hotels and where applied it is minimal. The purpose of this study was to determine the relationship between Entrepreneurial Orientation, organisational culture adaptability and performance of Christian Faith-Based Hotels in Kenya. This study was anchored on the epistemology philosophy and adopted a positivist approach. The study used the mixed methods approach guided by a cross-sectional survey research design. The variable items for organisational culture adaptability and performance were measured using the five-point Likert scale and using the Denison's organisational survey instruments. The population of the study included 72 managers and 1878 junior staff from 24 Christian faith-based hotels in Kenya. Structural equation models (SEM) and an MMR model were fitted to assess the objective of the study. Based on the SEM and MMR models, the study found that adaptability has a significant positive influencing on the performance of Christian Faith Based Hotels $\beta=0.520, t=2.444, p-$ value $=0.018$ ). The study also found that Entrepreneurial Orientation had a moderating role on the relationship between organisational culture adaptability and performance of Christian Faith Based Hotels based on the MMR model that had a significant change in $\mathrm{R}$ due to addition of the interaction term $(\mathrm{R}$-square change $=.063$, F-change $=4.293$, $\mathrm{p}$-value $=0.043$ ). The study is important to a business because it will encourage it to adapt to the environment to improve performance.
\end{abstract}

KEYWORDS: Organisational culture Adaptability, Entrepreneurial Orientation and performance.

\section{JEL CLASSIFICATION:}

DOI: $10.2478 /$ IJEK-2019-0003

Received: December $7^{\text {th }}, 2018$.

1st Revision: March $4^{\text {th }} 2019$.

Accepted: March 15 2019

Reference: Muriithi, R. W., Kyalo, T., \& Kinyanjui, J. (2018). Assessment of the relationship between entrepreneurial orientation, organisational culture adaptability and performance of Christian faith-based hotels in Kenya. International Journal of Entrepreneurial Knowledge, 7(1), 31-45. doi: 10.2478/ijek-2019-0003 


\section{INTRODUCTION}

Organisational culture can be defined as the set of values, beliefs, attitudes, expectations, understandings, norms shared by members of an organisation. It is passed from one generation of employees to the next and determines the standards for appropriate behaviour within the organisation (Hayton, 2010). Dasanayake and Mahakalanda, (2008) argue that organisational culture forms in response to the need for external adaptation and survival as well as internal integration. External adaptation and survival involve finding a niche to enable the organisation to cope with the changing environment. The reason for the popularity of organisational culture adaptability is the substantial relationship between the concept itself and its outcome such as gaining competitive advantage, enterprise's effectiveness and performance (Tidor, Gelmereanu, Baru and Morar, 2012). Thus, the purpose of this study was to determine the relationship between, Entrepreneurial Orientation, organisational culture adaptability and the performance of Christian faith-based hotels in Kenya.

Entrepreneurial orientation is the strategy-making processes that provide enterprises with a basis for entrepreneurial decisions and actions. The prime dimensions in entrepreneurial orientation are innovativeness, risk-taking, pro-activeness, competitive aggressiveness and autonomy (Mossete, 2013). Innovativeness is the pre-disposition to engage in creativity, problem solving and experimentation through the introduction of new products and services as well as technological leadership in new processes. Risk taking involves making bold decisions into the unknown and relatively emerging areas while borrowing heavily and committing significant resources to ventures in new environments. Proactiveness is an opportunity-seeking, forward-looking perspective symbolized by introduction of new products and services ahead of the competition and acting in anticipation of future. Autonomy is described as an independence of an individual or team to develop business vision and carry it to completion (Bhuian, Mengus, \& Bell 2005). Competitive aggressiveness refers to enterprise's tendency to compete with its competitors directly and intensely. It also refers to entrepreneurs who live in culture of achievement oriented (Bhuian, Mengus, \& Bell 2005).

Organisational performance is the outcome achieved in meeting internal and external goals of an organisation (Wei, Liu and Herndon 2011). Organisational performance is also a multidimensional construct including Customer-focused performance, product or service performance, financial and market performance, human resource performance and organisational effectiveness (Singh, 2011). Performance has become the most comprehensively researched dependent variable in past studies (Rauch et al., 2009; Wales et al., 2013a). In their early theorizing, Covin and Slevin (1991) reinforced this course in the literature by suggesting firm performance to represent the ultimate dependent variable in their model of organisation-level entrepreneurship.

The relationship between organisational culture adaptability and performance has been established, and an increasing body of evidence supports a linkage between an organisation's culture adaptability and its business performance (Denison and Fey, 2003). Interestingly, the study and the findings are emanating from a developed economic environment and very little is known about its relevance and applicability in a developing countries (Kotter and Heskett, 1992). It is against this background that the current study seeks to investigate the moderating role on the relationship between organisational culture adaptability and performance in Christian Faith-based hotels in Kenya as an attempt to replicate the Denison's model of culture in a developing country's context.

Hotel is one of the known forms of accommodation in tourism industry where accommodation is a place for someone to stay for a while away from home. Investments in the Christian faith based hotels by Christian organizations in Africa are spurred by the need to provide the missionaries and other workers from the church propagating gospel with amiable environments to spend their time during visits (Global Generosity Network, 2014). The need to generate revenues for Christian faith-based organisations has forced them to invest in businesses including hotels in the quest of realizing proceeds for the organisation. This assures greater growth of the organisations without relying heavily on the 
individual's contributions made by members and other benefactors (Evers, 2004). Hotels operate in a dynamic business environment characterised by intense Competition for resources and market share hence have become more challenging to manage and sustain their growth rate (Wandongo, 2008).Therefore the purpose of this study was to determine the relationship between Entrepreneurial Orientation, organisational culture adaptability and performance for Christian Faith Based Hotels in Kenya.

\subsection{Statement of the Problem}

There is a close relationship between organisational culture adaptability and performance though this relationship has not been researched exhaustively (Schneider, 2012). Over the past decade, a great deal has been written about adaptability (creating change, organisational learning and customer focus) and the important role it plays in successful performance of organizations (Denison 1990, Denison and Mishra 1995; Denison and Fey 2003; Daft 1998, Fisher and Alford 2000; Denison, Haaland \& Goeltzer 2004; Denison, Ward \& Lief 2004, Denison 2007, Amah, 2009, and Ongori, 2009). Despite this growth of scholarly publications on adaptability and organizational performance little empirical evidence exist in developing countries especially Kenya. There has been also a call by Denison, Haaland, and Goelzer, (2004) to investigate the organisational culture phenomenon in different cultural contexts, particularly in non-western Nations. To bridge this gap in literature this study sought to determine the relationship between entrepreneurial orientation, organisational culture adaptability and performance in Christian faith-based hotels in Kenya where Entrepreneurial Orientation was the moderating variable.

\section{$1.2 \quad$ Research Objective}

The objective of this study was to determine the Relationship between entrepreneurial orientation, organisational culture adaptability and performance of Christian faith-based hotels in Kenya.

\section{THEORETICAL BASES}

\section{1: Organisational culture adaptability concept}

Adaptability is one of the four organisational culture traits that profoundly influence the performance of an organisation. It deals with the relationship between the organisation and its environment and it acknowledges Schein's idea that organisations have to balance internal processes with external adaption processes (Loisch, 2007). The adaptability trait consists of three sub-points (Denison Consulting, retrieved in May 2013). According to Calori and Sarnin (1991), in a highly adaptive organisation the satisfaction and fulfilment of customer demands have utmost importance. To reach that goal, to stay in the market and be competitive, the organisation is willing to adapt to any changes and to try out new ideas (Caroli and Sarin, 1991, cited by Loisch, 2007).

\section{2: $\quad$ Entrepreneurial Orientation Concept}

Several studies have tested the moderating role of entrepreneurial orientation, including Ndungu (2012) in his study on role of entrepreneurial on relationship between information security management and firm performance, Lumpkin \& Sloat (2001) in their study on do family firms have entrepreneurial orientation? Wiklund \& Shepherd (2003) in their study on knowledge-based resources, entrepreneurial orientation and the performance of small and medium-sized businesses and Richard, Barntt, Dwyer, and Chadwick (2004) in their study on cultural diversity in management, firm performance, and the moderating role of entrepreneurial orientation on dimensions.

\section{3: Theoretical Framework}

\subsubsection{The Schumpeterian theory on innovation}


Schumpeter portrayed entrepreneurship as one making a difference. The entrepreneur breaks up with established practices and destroys the status quo while moving the market forward in a different direction (Mintzberg at al., 1998). The theory is relevant to this study since there is a relationship between product and process innovation to the business performance.

\subsubsection{Denison Organisational Culture Model}

This study adopted Denison Organisational culture Model where adaptability trait was one of the key characteristics. Adaptability is based on the idea that norms and beliefs that enhance an organization's ability to receive, interpret and translate signals from the environment into internal organizational and behavioural changes promote its survival, growth and development (Denison, Janovics, Young \& Cho, 2006). Adaptable organizations are driven by their customers, take risks and learn from their mistakes and have the capability and experience at creating change (Nadler, 1998; Senge, 1990). Such organizations are continuously changing their systems to promote improvements and provide value for their customers (Stalk, 1988).

\subsection{Conceptual framework}

Figure 1. Conceptual framework

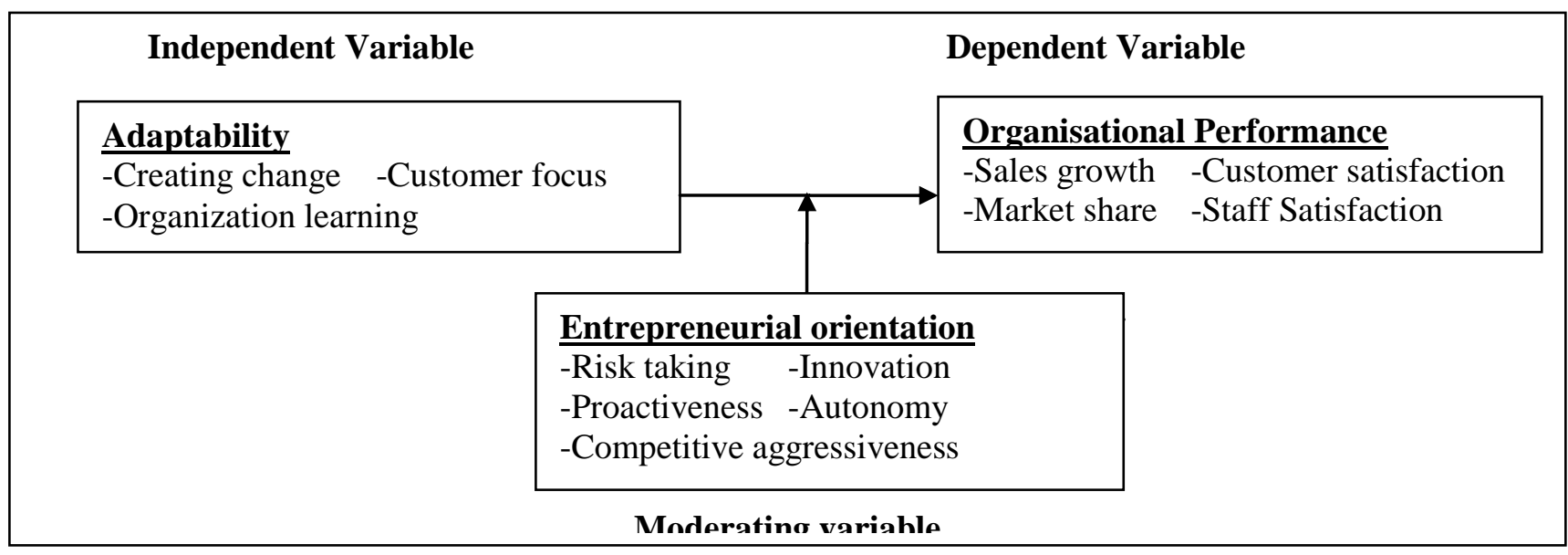

(Source: Research Data 2018)

The conceptual framework shows the moderating role of entrepreneurial orientation on the relationship between organizational culture adaptability and performance of Christian faith based hotels in Kenya. The study adopted Denison Organizational culture Model.

\subsection{Empirical review}

\subsubsection{Adaptability and organisational performance}

Wilkins and Ouchi (1983) and Denison (2000) explored the relationship between culture and organisational performance, arguing that cultures are more adaptive and more easily developed than previously thought. Anand and Ward (2004) discussed the idea of environmental fit and manufacturing flexibility in a study of U.S. manufacturers. Their research indicated the culture plays a crucial role in the type of required flexibility to best fit the enterprise and impact performance. Researchers do note that culture can remain linked with performance only if they are capable of adapting to the changing environment (Ogbonna \& Harris, 2000). According to Swanson and Davis (2003) in their study of customer quality practices they state that the customer is always right this in reference to the fact that the customer generates revenue to the company in which the company benefits through profits. This 
applies to government entities that may be providing services where the end result is the customer satisfaction rating.

Performance is a complex and dynamic concept which has been conceptualized in two ways namely the drivers of performance and the results of performance (Olsen, 2008). Organisational performance is concerned with the overall productivity of an organisation regarding stock turnover, customers, profitability and market share. Both quantitative and qualitative methods may measure performance. This study used financial measures such as profitability and sales growth and non-financial measures such as market share, service quality as well as customer and low staff turnover (Olsen, 2008). Researchers do note that culture can remain linked with performance only if they are capable of adapting to the changing environment (Ogbonna \& Harris, 2000). Researchers postulate organisational behaviour (flexibility and speed) is a reflection of this environmental change (Eisenhardt \& Brown, 1998; Lamberg, Tikkanen, Nokelainen, \& Suur-Inkeroinen, 2009), and fully adaptive enterprises will imitate its pace.

\subsubsection{Moderating Role of Entrepreneurial Orientation}

Several studies have tested the moderating role of entrepreneurship orientation, including Wiklund \& Shepherd (2003) in their study on knowledge based resources, entrepreneurial orientation and the performance of small and medium sized business: and Richard, Barntt, and Chadwick (2004) in their study on cultural diversity in management, firm performance, and the moderating role of entrepreneurial orientation on dimensions. Shihab, Wismiarsi and Sine (2011) investigated the relationship between organizational culture (OC) and entrepreneurial orientation (EO). Ndungu (2012) evaluated the role of entrepreneurial orientation on relationship between information security management and firm management.

\section{AIM AND METHODOLOGICAL BASES}

This study was guided by an epistemological research philosophy and employed the positivistic research paradigm. A mixed methods research guided by a cross-sectional survey design was used which extensively tested the analysis of the relationship between variables. The target population of this study was composed of 72 managers from 24 registered Christian faith-based hotels in Nairobi and Mombasa. Stratified sampling was used to select the hotels of each category of the study. That is the rated hotels and unrated hotels. The study used the entire population of the general managers and two departmental managers as a sample size for the managers. Krejcie \& Morgan table for the predetermined population as the basis for sample size determination was used to sample the employees. In the case of the employees' population, the study had a sample size of 72 managers and 322 subordinate staffs that were evenly distributed in the two study areas based on the strength of the population making a total sample size of 394.

This study used a self-administered questionnaire to obtain primary data. The questionnaire consisted of close-ended questions and was based on a 5 Likert's scale. Face validity was estimated by use of correlations between the objective and subjective items utilized in the scales. Content validity was assessed through review and verification of the extant literature for the items contained in the questionnaire. Finally, construct validity was assessed from the correlations of items. A pilot test was conducted to enhance the questionnaire design by modifying the survey based on feedback from the pilot test and subsequently implementing the revised survey. To establish the reliability of the research instruments, the test-retest method whereby the pilot study respondents were issued with questionnaires for them to fill and the same questionnaires were subjected to a retest to see how the response was. The reliability coefficient was computed using Pearson's Product Correlation Coefficient. 
This study used a Likert scale as developed by Rensis Likert, to examine how strongly subjects agree or disagree with a statement (Cooper \& Schindler, 2011). Statistical Package for Social Sciences (SPSS) version 21.0 was used for data entry, data cleaning and data analysis. Descriptive statistics were used to describe the characteristics of the sample and Structural Equation Models (SEMs) were fitted for inferential analysis. SEM is a combination of confirmatory factor analysis and multiple regression analysis used to assess causal relationships between constructs that are unobserved directly but measured using indicators. AMOS (Analysis of Moment structures) software was used for SEM. A Moderated Multiple Regression analysis (MMR) was carried out using Ordinary Least Square model (OLS) to assess the moderating effect. Interaction effects were tested in the MMR Model equations involving scores of a continuous predictor variable $\mathrm{Y}$, scores for predictor variable $\mathrm{X}$ and scores for a second predictor variable $Z$ hypothesized to be a moderator (Aquinis \& Gottfedson, 2010). The study models were assessed for the assumptions of normality, linearity, homoscedasticity, non-autocorrelation and non-multicollinearity.

\section{RESULTS AND DISCUSSIONS}

The total questionnaires completed and returned were 292 out of the 394 that were administered. This translates to a response rate of $74.1 \%$. Babbie (1990) stated that a response rate of $50 \%$ is adequate while Bailey (1987) set an adequate response rate at 75\%. According to Edwards et al (2002), a response rate of below $60 \%$ is considered poor while of between $60 \%$ and $80 \%$ is adequate. Therefore, the Response rate of 74.1 as reflected in this study was adequate to enable the researcher draw conclusions and generate the research findings.

\subsection{Adaptability to the External Business Environment in Christian Faith Based Hotels}

The responses to the questions used to measure adaptability as shown in table 1 were coded in to an ordinal scale from $1=$ strongly disagreement to 5 strongly agreement. On adaptability to external environment, the respondents rated creating change at a mean of 2.7 with a standard deviation of 1.2. This is an indication that the respondents in Christian faith-based hotels believe that there is a moderate creation of change in these hotels to adapt to the external environment. The respondents feel that the Christian faith-based hotels are not effective in adapting to change in the external environment. The respondents also rated the significance of customer focus in Christian faith-based hotels at a mean of 3.5 with a standard deviation of 1.2. This implies that customer focus has moderately been put in place in the Christian faith-based hotels and that in Christian faith-based hotels, there is significant customer focus in adapting to changes in the external environment. The significance of organisational learning in Christian faith-based hotels was rated at a mean of 3.6 with a standard deviation of 0.9. This indicates that there is moderate organisational learning in the Christian faith-based hotels and that in Christian faith-based hotels, organisational learning is quite involved in adapting to changes in external environment.

Table 1: Descriptive analysis of Adaptability

\begin{tabular}{|l|c|c||}
\hline Statement & Mean & Sdv \\
\hline $\begin{array}{l}\text { Creating Change } \\
\text { The way things are done is very flexible and easy to change }\end{array}$ & 2.5 & 1.3 \\
\hline We respond well to competitors and other changes in the business environment & 2.2 & 1.2 \\
\hline New and improved ways to do work are continually adopted & 2.6 & 1.3 \\
\hline Attempts to create change seldom meet with resistance & 3.2 & 1.1 \\
\hline Different parts of the organisation often cooperate to create change & 2.9 & 1.3 \\
\hline Average & $\mathbf{2 . 7}$ & $\mathbf{1 . 2}$ \\
\hline
\end{tabular}




\begin{tabular}{|l|l|l||}
\hline $\begin{array}{l}\text { Customer Focus } \\
\text { I view failure as an opportunity for learning and improvement }\end{array}$ & 4.2 & 0.7 \\
\hline I view failure as a disarrangement and defeat & 1.8 & 1.0 \\
\hline In this hotel, innovations and risk-taking are encouraged and rewarded & 3.9 & 1.0 \\
\hline Learning is an important objective in the hotels day-to-day work & 4.2 & 0.8 \\
\hline Average & $\mathbf{3 . 6}$ & $\mathbf{0 . 9}$ \\
\hline $\begin{array}{l}\text { Organisational Learning } \\
\text { I view failure as an opportunity for learning and improvement }\end{array}$ & 4.2 & 0.7 \\
\hline I view failure as a disarrangement and defeat & 1.8 & 1.0 \\
\hline In this hotel, innovations and risk-taking are encouraged and rewarded & 3.9 & 1.0 \\
\hline Learning is an important objective in the hotels day-to-day work & 4.2 & 0.8 \\
\hline Average & $\mathbf{3 . 6}$ & $\mathbf{0 . 9}$ \\
\hline
\end{tabular}

(Source: Research Data 2018)

\subsection{Measurement model}

To assess the objectives of the study, the researcher used Structural equation modelling (SEM) for inferential analysis. The process used a 2 step approach which included carrying out analysis measurement model and confirmatory structural SEM model of the study constructs (Miles \& Shevlin, 2003; Anderson and Gerbing, 1988). The measurement model involved the assessment of the unidimensionality of the constructs by studying the underlying structure of the constructs and variables for the data collected. The summary statistics of the measurement model from the subordinate employees' data is shown in table 8. From Exploratory factor analysis, 7 indicators that had factor loadings less than 0.4 were expunged while the rest were retained. Cronbach alpha statistics were above 0.7 for each construct and retained indicators, the Keiser-Meyer Olkin (KMO) statistics were above the 0.5 threshold and the Bartlett's test of sphericity had p-values less than 0.05 (Hair et al., 2010). Construct validity was confirmed by assessing for convergent validity using the Average variances extracted (AVEs) which were all found to be above 0.5 and discriminant validity was shown by the squared multiple correlations which were all less than the relative AVEs (Fornell \& Larcker, 1981). These analyses confirmed that the measurements were reliable and exhibited construct validity hence unidimensionality of the construct.

Table 2: Measurement model summary statistics

\begin{tabular}{|c|c|c|c|c|c|}
\hline & & $\begin{array}{l}\text { Factor } \\
\text { Loading }\end{array}$ & $\begin{array}{c}\text { Squared multiple } \\
\text { correlations }\end{array}$ & AVE & \\
\hline \multirow[t]{8}{*}{ Adaptability } & AdaptabilityA1 & -0.621 & 0.200 & 0.771 & $\mathrm{KMO}=0.615$ \\
\hline & AdaptabilityA3 & -0.513 & 0.107 & & \multirow{2}{*}{$\begin{array}{l}\text { Bartlett's } \quad \chi^{2}= \\
450.301\end{array}$} \\
\hline & AdaptabilityB1 & 0.930 & 0.589 & & \\
\hline & AdaptabilityB2 & 0.872 & 0.762 & & P-value $=0.000$ \\
\hline & AdaptabilityB3 & 0.832 & 0.706 & & \\
\hline & AdaptabilityB4 & 0.696 & 0.360 & & \\
\hline & AdaptabilityB5 & 0.873 & 0.770 & & \\
\hline & AdaptabilityC3 & 0.831 & 0.488 & & \\
\hline \multirow[t]{4}{*}{ Performance } & Performance1 & 0.806 & 0.612 & 0.700 & $\mathrm{KMO}=0.671$ \\
\hline & Performance 3 & 0.570 & 0.233 & & \multirow{2}{*}{$\begin{array}{l}\text { Bartlett's } \quad \chi^{2}= \\
481.169\end{array}$} \\
\hline & Performance4 & 0.697 & 0.445 & & \\
\hline & Performance 5 & 0.726 & 0.522 & & P-value $=0.000$ \\
\hline
\end{tabular}




\begin{tabular}{|c|c|c|c|c|c|}
\hline & Performance6 & 0.837 & 0.741 & & \\
\hline & Performance 7 & 0.735 & 0.495 & & \\
\hline & Performance8 & 0.543 & 0.225 & & \\
\hline & Performance9 & 0.566 & 0.273 & & \\
\hline & Performance10 & 0.677 & 0.360 & & \\
\hline & Performance11 & 0.781 & 0.495 & & \\
\hline & Performance12 & 0.709 & 0.471 & & \\
\hline \multirow{12}{*}{$\begin{array}{l}\text { Entre } \\
\text { Orientation }\end{array}$} & EntreOrientation1 & 0.580 & 0.186 & 0.700 & $\mathrm{KMO}=0.612$ \\
\hline & EntreOrientation2 & 0.656 & 0.333 & & \multirow{2}{*}{$\begin{array}{l}\text { Bartlett's } \\
605.35\end{array}$} \\
\hline & EntreOrientation3 & 0.690 & 0.522 & & \\
\hline & EntreOrientation4 & 0.830 & 0.410 & & P-value $=0.000$ \\
\hline & EntreOrientation5 & 0.791 & 0.616 & & \\
\hline & EntreOrientation6 & 0.437 & 0.176 & & \\
\hline & EntreOrientation 7 & 0.531 & 0.206 & & \\
\hline & EntreOrientation8 & 0.795 & 0.568 & & \\
\hline & EntreOrientation9 & 0.703 & 0.391 & & \\
\hline & EntreOrientation 10 & 0.818 & 0.703 & & \\
\hline & EntreOrientation11 & 0.800 & 0.573 & & \\
\hline & EntreOrientation 12 & 0.597 & 0.244 & & \\
\hline
\end{tabular}

(Source: Research Data 2018)

\subsection{Structural equation model}

The confirmatory structural models were constructed in steps. The models were tested for fitness using both absolute and incremental fit indices. Table 9 represents the fitness indices from both datasets. All the models fitted met the desired fitness thresholds. The Root Mean Squared Error of approximation (RMSEA) was found to adequately be below the desired threshold of 0.08 for all the models which also met the other fit indices requirements such as the normed fit index (NFI), comparative fit index (CFI), goodness of fit index (GFI) and parsimony fitness PGFI and PNFI.

Table 3: Model fit indices

\begin{tabular}{|c|c|c|c|c|c|c|c|c|c|c||}
\hline & & \multicolumn{2}{|c|}{ Chi-square } & & & & & & & \\
\hline Data & & $\boldsymbol{\chi}^{\mathbf{2}}$ & Sig. & CFI & NFI & GFI & SRMR & RMSEA & PGFI & PNFI \\
\hline Mgt. & Statistic & 545.941 & 0 & 0.891 & 0.824 & 0.854 & 0.065 & 0.068 & 0.536 & 0.594 \\
\hline Sub & Statistic & 545.941 & 0 & 0.916 & 0.848 & 0.866 & 0.076 & 0.063 & 0.546 & 0.614 \\
\cline { 2 - 11 } & Cut-off & \multicolumn{2}{|c|}{ P-value $<0.05$} & $\geq 0.9$ & $\geq 0.9$ & $\geq 0.9$ & $\leq 0.08$ & $\leq 0.08$ & $\geq 0.5$ & $\geq 0.5$ \\
\hline
\end{tabular}

(Source: Research Data 2018)

This relationship between organisational culture adaptability and performance of CFBHs was confirmed by the model fitted from the data collected. The coefficient regression weight estimate of adaptability on performance as shown on the path diagram in figure 2 is 0.132 . other coefficients show the coefficient estimates of the retained observed indicators measuring the constructs. 
Figure 2: Path diagram on adaptability and performance

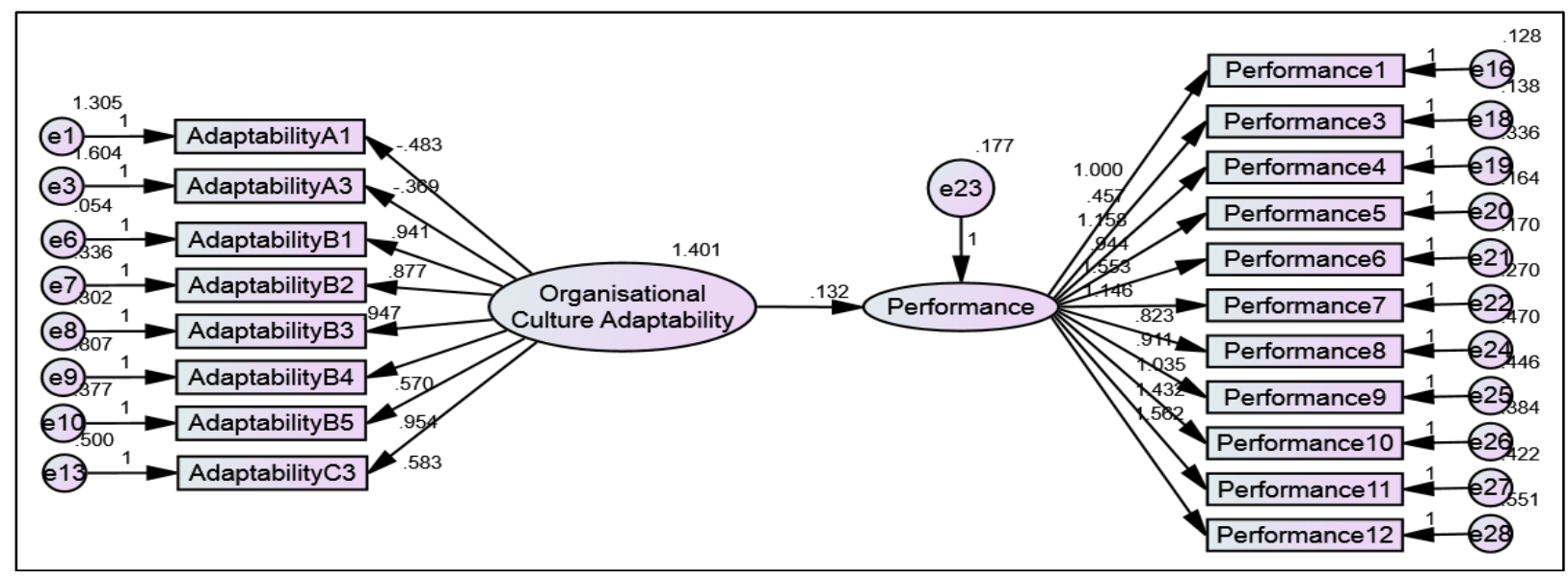

(Source: Research Data 2018)

The coefficient of adaptabilty on performance based on the magagement data was found to be significant as shown in table 11. The path coefficient estimate of adaptability is 0.132 with a critical ratio (CR) of 2.455. The CR is greater than the tabulated $1.96 \mathrm{Z}$ score at 0.05 level of significance thus implying a significant coefficient estimate. This confirms the results also found based on the subordinate employees data that organisation culture adaptability has a significant influence on performance of CFBHs in Kenya. The results yields the eqution below.

$Y=.132 X+\varepsilon$

Where $\mathrm{Y}$ - performance

X - adaptability

Table 4: Regression Weights on adaptability and performance

\begin{tabular}{|l|l|l|r|r|r|r||}
\hline & & & Estimate & S.E. & C.R. & P \\
\hline Performance & $<---$ & Adaptability & .132 & .054 & 2.455 & .014 \\
\hline AdaptabilityC3 & $<---$ & Adaptability & .583 & .085 & 6.884 & $* * *$ \\
\hline AdaptabilityB5 & $<---$ & Adaptability & .954 & .079 & 12.133 & $* * *$ \\
\hline AdaptabilityB4 & $<---$ & Adaptability & .570 & .106 & 5.353 & $* * *$ \\
\hline AdaptabilityB3 & $<---$ & Adaptability & .947 & .072 & 13.183 & $* * *$ \\
\hline AdaptabilityB2 & $<---$ & Adaptability & .877 & .074 & 11.874 & $* * *$ \\
\hline AdaptabilityB1 & $<---$ & Adaptability & .941 & & & \\
\hline AdaptabilityA3 & $<---$ & Adaptability & -.369 & .148 & -2.494 & .013 \\
\hline AdaptabilityA1 & $<---$ & Adaptability & -.483 & .134 & -3.597 & $* * *$ \\
\hline Performance1 & $<---$ & Performance & 1.000 & & & \\
\hline Performance3 & $<---$ & Performance & .457 & .129 & 3.534 & $* * *$ \\
\hline Performance4 & $<---$ & Performance & 1.158 & .228 & 5.075 & $* * *$ \\
\hline Performance5 & $<---$ & Performance & .944 & .169 & 5.574 & $* * *$ \\
\hline Performance6 & $<---$ & Performance & 1.553 & .225 & 6.903 & $* * *$ \\
\hline Performance7 & $<---$ & Performance & 1.146 & .212 & 5.403 & $* * *$ \\
\hline Performance8 & $<---$ & Performance & .823 & .237 & 3.465 & $* * *$ \\
\hline Performance9 & $<---$ & Performance & .911 & .237 & 3.848 & $* * *$ \\
\hline Performance10 & $<---$ & Performance & 1.035 & .230 & 4.489 & $* * *$ \\
\hline \hline
\end{tabular}




\begin{tabular}{|l|l|l|r|r|r|r||}
\hline \hline Performance11 & $<---$ & Performance & 1.432 & .265 & 5.398 & $* * *$ \\
\hline Performance12 & $<---$ & Performance & 1.562 & .298 & 5.246 & $* * *$ \\
\hline
\end{tabular}

(Source: Research Data 2018)

The moderating variable and interaction terms were added the model to assess the moderating effect of entrepreneurial orientation. The interaction term was a computed variable as an interaction between the latent vriables organisational culture adaptability and entrepreneurial orientation was generated and included in the structural equation model. Figure 4 shows the ath diagram of the model including EO and the interation term as predictors. The path coefficient estimate of entrepreneurial orientation on performance is -0.507 while the path coefficient estimate the interaction term between adaptability and $\mathrm{EO}$ on performance is 0.106 .

Figure 3: Path diagram on the moderating effect of EO

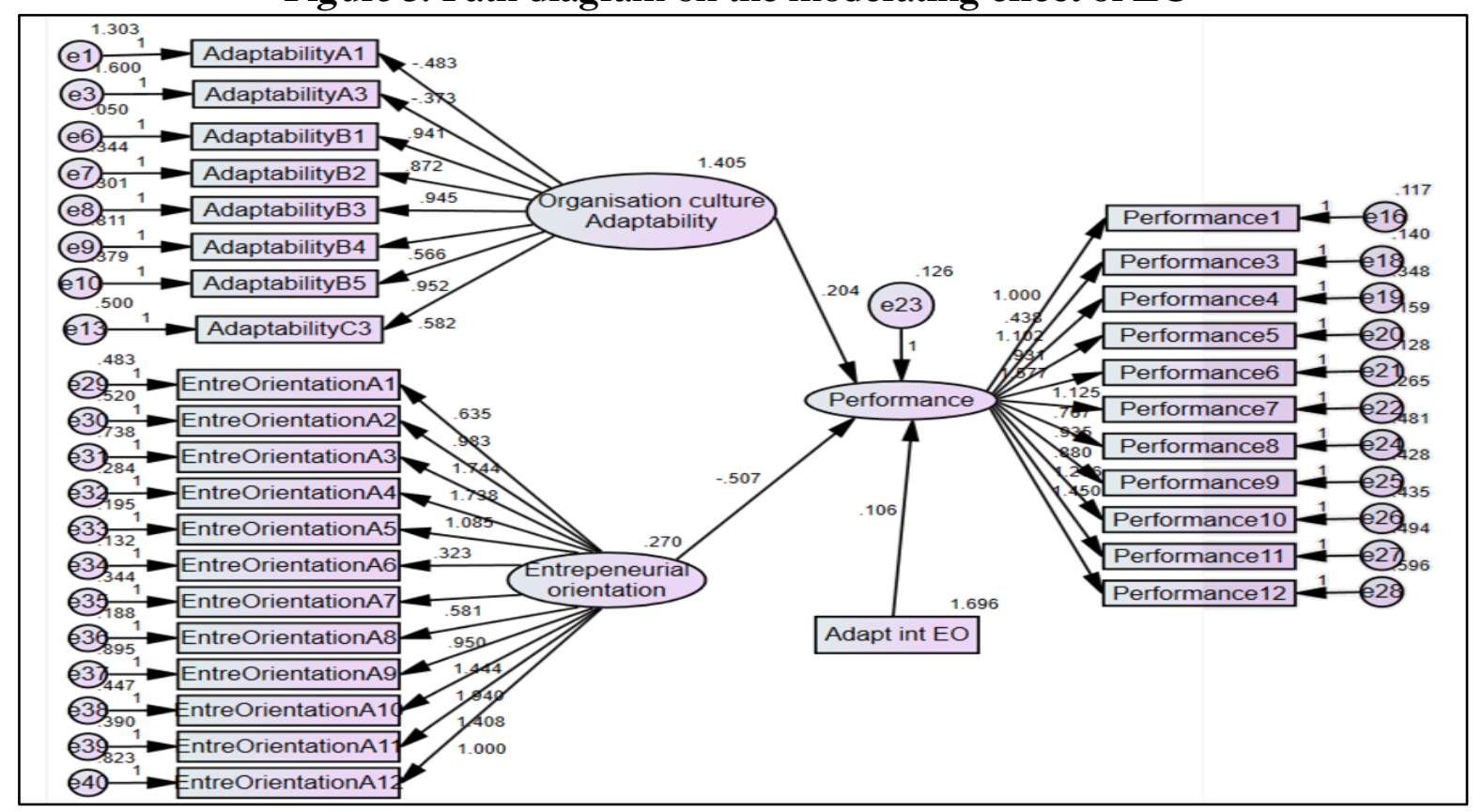

(Source: Research Data 2018)

The path coefficient estimate of EO -0.507 has a critical ratio (CR) of 4.190 which is greater than the tabulated $1.96 \mathrm{Z}$ score at 0.05 level of significance. This implies that the coefficient estimate is significant. The coefficient estimate of the interaction term between entreprenurial orientation (EO) and adaptability was found to be significant as shown in table 12. The path coefficient estimate 0.106 was found to have a critical ratio (CR) of 2.549 which is greater than the tabulated $1.96 \mathrm{Z}$ score at 0.05 level of significance. This implies that the coefficient estimate is significant. The significance of the interaction effect implies a significant positive moderating effect of $\mathrm{EO}$ on the relationship between adaptability and performance.

$$
\begin{aligned}
& Y=.204 X-0.507 Z+0.106 X * Z+\varepsilon \\
& \text { Where } \mathrm{Y} \text { - performance } \\
& \text { X - adaptability } \\
& \text { Z - entrepreneurial orientation }
\end{aligned}
$$

Table 5: Regression Weights on the moderating effect of EO

\begin{tabular}{|r|r|l|r|r|r|r||}
\hline & & & Estimate & S.E. & C.R. & P \\
\hline Performance & $<---$ & Adaptability & .204 & .049 & 4.190 & $* * *$ \\
\hline Performance & $<---$ & EO & -.507 & .168 & -3.009 & .003 \\
\hline
\end{tabular}




\begin{tabular}{|l|l|l|l|l|l|l||}
\hline Performance & $<---$ & Adaptability interaction EO & .106 & .042 & 2.549 & .011 \\
\hline
\end{tabular}

(Source: Research Data 2018)

\subsection{Moderated multiple regression}

To confirm the moderating effect, a moderated multiple regression (MMR) was carried out which was a three-step hierarchical Ordinary least squares (OLS) regression analysis. Model 1 of the MMR only included the adaptability as a predictor. The second model included entrepreneurial orientation as a predictor while model three included the interaction term as a predictor. The change in $\mathrm{R}$-square was assessed in each step of the analysis. The R-square (the explanatory power) is the variation in performance explained by the variation in the predictors in a given model. Model 1 has an R-square of 0.106 implying that $10.6 \%$ of the variance in performance is explained by the variation of adaptation. The change in $\mathrm{R}$ in model 2 is 0.084 and the F-change has a p-value of 0.024 implying that the addition of entrepreneurial orientation has a significant improvement to the explanatory power of the model. The addition of the interaction term also has a significant improvement on the model as shown by the $\mathrm{R}$-square change of 0.063 and the F-change with a p-value of 0.043 . The significant change in the Rsquare due to addition of the interaction term between entrepreneurial orientation and adaptability shows that EO has a moderating effect on the relationship between adaptability and performance.

The MMR model confirms that EO has a significant positive moderating effect on the relationship between adaptability and performance. The interaction term between adaptability and EO has a coefficient estimate of 0.241 with a $\mathrm{p}$-value of 0.043 . The $\mathrm{p}$-value is less than 0.05 level of significance thus implying that the interaction is significant hence a significant moderating effect. The coefficient estimates of adaptability and EO in model 3 were found to be 0.520 and 0.385 respectively. These coefficients were significant based on the p-values of the estimates which were 0.018 and 0.009 respectively which are both less than 0.05 level of significance. The equation based on the final MMR model is given by;

$$
\begin{aligned}
& \mathrm{Y}=.520 \mathrm{X}-0.385 \mathrm{Z} \\
& \text { Where } \mathrm{Y}
\end{aligned}
$$

\begin{tabular}{|c|c|c|c|c|c|c|c|c|c|}
\hline & \multicolumn{3}{|c|}{ Model 1} & \multicolumn{3}{|l|}{ "Model 2} & \multicolumn{3}{|c|}{ Model 2} \\
\hline & Beta & $T$ & P-value & Beta & $T$ & P-value & Beta & $\mathbf{T}$ & P-value \\
\hline \multicolumn{10}{|c|}{ Independent variable } \\
\hline Constant & 0.000 & 0 & 1 & 0.000 & 0 & 1 & 0.035 & 0.276 & 0.783 \\
\hline Adaptability & 0.326 & 2.509 & 0.015 & 0.283 & 2.243 & 0.029 & 0.52 & 2.444 & 0.018 \\
\hline \multicolumn{4}{|c|}{ Entrepreneurial Orientation } & -0.292 & -2.318 & 0.024 & -0.385 & $\begin{array}{c}- \\
2.711\end{array}$ & 0.009 \\
\hline \multirow{2}{*}{\multicolumn{5}{|c|}{$\begin{array}{l}\text { Interaction Effect } \\
\text { Adaptability intersection En }\end{array}$}} & & & & & \\
\hline & & & & & & & 0.241 & 2.072 & 0.043 \\
\hline $\mathrm{R}$ & $.326 a$ & & & $.436 \mathrm{~b}$ & & & $.503 c$ & & \\
\hline R Square & 0.106 & & & 0.19 & & & 0.253 & & \\
\hline Adj R Square & 0.089 & & & 0.159 & & & 0.224 & & \\
\hline
\end{tabular}

Table 6: Moderated Multiple Regression 


\begin{tabular}{|l|l|l|l|l|l|l|l|l|l||}
\hline ANOVA F & 6.296 & & 0.015 & 6.099 & & 0.004 & 5.758 & & 0.002 \\
\hline $\begin{array}{l}\text { R Square } \\
\text { Change }\end{array}$ & 0.106 & & & 0.084 & & & 0.063 & & \\
\hline Change in F & 6.296 & & 0.015 & 5.373 & & 0.024 & 4.293 & & 0.043 \\
\hline
\end{tabular}

(Source: Research Data 2018)

Figure 5 shows a graphical presentation generated by plotting the estimates of the MMR model. The graph shows the positive moderating effect on the relationship between adaptability and performance. The slope of the graph between organisational culture adaptability and performance when EO is low is slow depicted by an almost flat line implying a very slow influence of adaptability on performance. When the level of EO is increased, the slope becomes steeper as depicted by medium EO and an even steeper slope at high EO. This shows that as the level EO increases, the relationship between organisation culture adaptability and performance of Christian faith-based hotels becomes stronger as adaptability has a higher influence on the performance with higher levels of EO.

\section{Figure 4: graphical presentation of the moderating effect of EO}

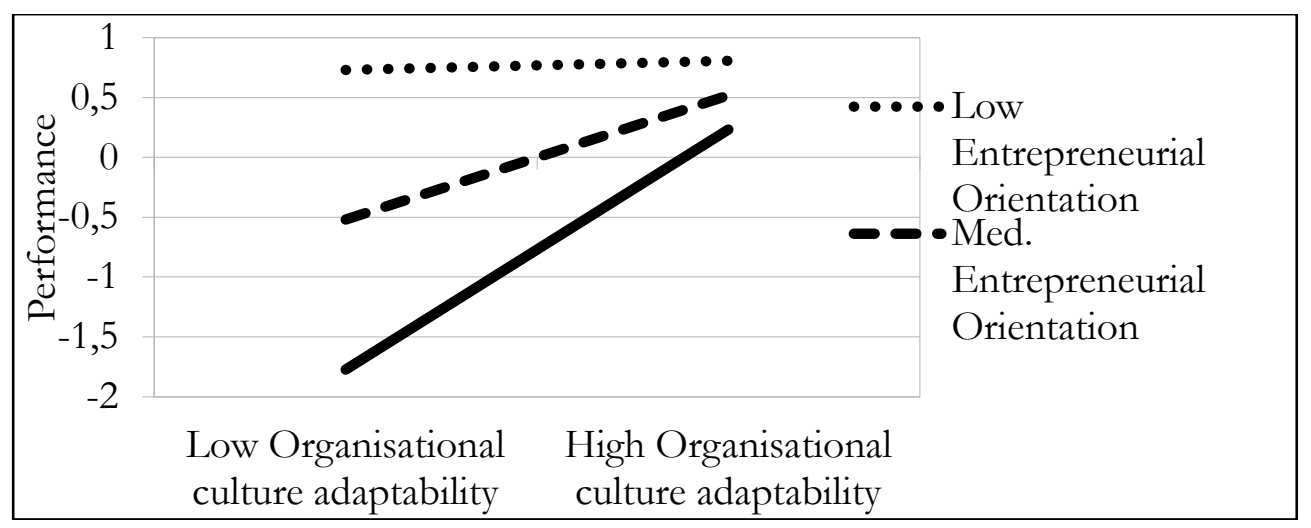

(Source: Research Data 2018)

\section{CONCLUSION}

Customer focus has moderately been put in place in the Christian faith-based hotels while organisational learning is quite involved in adapting to changes in the external environment; where they emphasize on organisational learning in adapting to changes in external environment.

Operations in Christian faith-based hotels are flexible thus positively influencing the performance of these organisations. They are manageable and are easy to change and there is cooperation in change creation and employees welcomes changes as long as it is for the good and growth of the hotel. Moreover, Christian faith-based hotels are effective in some aspects of creating change to adapt to the external business environment.

In the case of innovation, most of the hotels find non-product ways to create value for a new or existing customer, such as advertising, distribution, or other communications. Most of the hotels improve the quality or the number of features of their products or services to curb competitors. It seems that a large number of Christian faith-based hotels takes the risk of missing an opportunity with the same weight at the risk of failure. On competitive aggressiveness, the most of the faith-based hotels come up with new ideas/innovations to counter their competitors.

\subsection{Recommendation}


Christian Faith Based Hotels in Kenya need to learn how to create new advantages that will keep them new step ahead of their competitors through differentiation.

The faith-based hotels' management should welcome innovation from the skilled employees and allow them to enact their work freely.

Faith-based hotels need to possess unique advantages to their competitors if they are to survive especially in the global competitive environment and if they are to improve their market share.

Managers in the Christian faith-based hotels should see to it that different parts of the organisation often cooperate to create change.

Faith-based hotels Managers need to ensure that the strategies they put in place can respond well to competitors and adapt to other changes in the business environment.

\subsection{Suggestion for Further Studies}

Given the study limitations, it is important that other studies should be carried out focusing on the following dimensions:

A similar study should be conducted in a different regions other than Nairobi and Mombasa County to check for consistency in the findings and incorporate a more diverse perspective for more insights on how to enhance the performance of Christian faith-based hotels

Other studies should also be conducted focusing on other potential determinants of organisational culture in faith-based hotels other than adaptability to the external business environment.

More Studies should be done on other types of faith-based organisations in relation to entrepreneurship.

\section{REFERENCES}

Amah, E. (2009). Corporate culture and organizational effectiveness: A Study of the Nigerian Banking Industry. An Unpublished PhD Thesis. Faculty of Management Sciences, University of Port Harcourt, Nigeria.

Anderson, J. C., \& Gerbing, D. W. (1988). Structural equation modeling in practice: a review and recommended two-step approach. Psychological Bulletin, 103(3), 411-423.

Anand, G., \& Ward, P.T. (2004). Flexibility and Performance in Manufacturing: Coping with Dynamic Environments. Production and Operations Management, 13(4), 369-385.

Aquinis, H., \& Gottfrdson, R. K. (2010). Best Practice recommendations for Estimating interactions effects using moderated multiple regression. Journal of organizational behavior, 31(6), 776-786.

Babbie, Earl R. (1990). Survey research methods. Belmont, Calif. :Wadsworth Pub. Co.

Bailey, K.D., (1987). Methods of Social Research. 3rd Edition, New York: the Free Press.

Bhuian, S.N., Menguc, B., \& Bell, S. J. (2005). Just Entrepreneurship Enough: The Moderating effect of entrepreneurship on the relationship between marketing orientation and performance. Journal of Business Research, 58, 9-17.

Calori, R., \& Sarnin, P. (1991). Corporate Culture and Economic Performance: A French Study. Organization Studies, 12(1): 49-74.

Cooper, D.R., \& Schindler, P.S. (2011). Business research methods, (11th edition). New York: MC Graw-Hill.

Covin, J. G., \& Slevin, D. P. 1991. A conceptual model of entrepreneurship as firm behavior. Entrepreneurship Theory and Practice, 16(1), 7-24.

Daft (2000). Organization Theory and Design. Houston, TX U.S.A.: South-Western College Publishing, Thomson Learning. 
Dasanayake, S. W. S.B. and Mahakalanda I. (2008) A Literature Survey on Organisational Culture and Innovation. Global Business and Management Research, 539-550.

Denison Consulting, (2013).The Denson Organizational Culture Model. Retrieved from http: //www.denisonconsulting.com/model-surveys/Denison-model/ocs-mission.

Denison, D.R., Haaland, R., \& Goelzea, S.P. (2004). Corporate culture and organizational effectiveness: Is there a similar pattern around the world? Advances in Global Leadership, 3, 205-227.

Denison, D. R., Lief, C., \& Ward, J. L. (2004). Culture in family-owned enterprises: Recognizing and leveraging unique strengths. Family Business Review, 17, 61-70.

Denison,D. R (2007). Denison Consulting An Arbor Zurich Shanghai.

Denison, D. R., Janovics, J., Young, J., \& Cho, H. J. (2006). Diagnosing organizational cultures: Validating a model and method. Working Paper, Denison Consulting Group Retrieved 25.11, 2018, from $\quad$ https://www.researchgate.net/publication/228801211 Diagnosing organizational cultures Validating a model and method.

Denison, D.R., \& Mishra, A.K. (1995). Towards a Theory of Organizational culture and effectiveness organization science, 6(2):204-223.

Denson, D.R. (1990). Corporate culture and organizational effectiveness New York: John Wiley and sons.

Denison, D. R. (2001). Organizational culture: Can it be a key lever for driving organizational change?

In C. Cooper, Cartwright, S., \& Earley, P. (Eds.), International handbook of organizational culture and climate. Chichester: Wiley, 347-372.

Denson, D.R. (2000). Organizational culture: can it be a key lever for driving organizational change. S. Cart Wright \& C. Cooper (eds.), The handbook of organization culture. London: Joley \& sons.

Edwards, P., Roberts, I., Clarke, M., DiGuiseppi, C., Pratap, S., Wentz, R., (2002). Increasing response rates to postal questionnaires: Systematic review. British Medical Journal, 324.

Eisenhardt, K.M., Brown, S.L. (1998). Time pacing: Competing in markets that won't stand still. Harvard Business Review, 76(2), 59-67.

Evers, A. (2004). The third sector in Europe. Massachusetts, USA: Edward Elgar publishing.

Fey, C. and Denison, D.R. (2003). 'Organizational culture and effectiveness' can American theory be applied in Russia? Oorganizational Science 14 (6) 686 - 706.

Fisher, C., \& Alford, R. (2000). "Consulting on culture." Consulting Psychology: Research \& Practice 52(3): 206-207.

Fornell, C., \& Larcker, D. F. (1981). Evaluating Structural Equation Models with Unobservable Variables and Measurement Error, Journal of Marketing Research 18(1), 39-50.

Global Generosity Network. (2014). An initiative of the world Evangelical Alliance, Mission Africa Trust Fund. Retrieved from https://www.ministrywatch.com/generosity-resources-list.pdf.

Hair, J. F., Black, W. C., \& Babin, B. J. (2010). Multivariate Data Analysis: A Global Perspective. Upper Saddle River, NJ: Pearson Prentice-Hall.

Hayton, (2010). National Culture and Entrepreneurship: A review of behavioral Research, Entrepreneurship Theory and practice 26 (4), 33.

Kotter, J.P., \& Heskett, J. L.(1992). Corporate culture and performance. New York: Macmillan.

Lamberg, J., Tikkanen, H., Nokelainen, T., \& Suur-Inkeroinen, H. (2009). Competitive dynamics, strategic consistency, and organizational survival. Strategic management Journal, 30, 45-60.

Ling, Y.\& Jaw, B. J. (2011). Entrepreneurial Leadership Human Capital Management and Global Competitive Journal of Chinese Human Resource Management, 2(2), 117-135.

Loisch, C.U., (2007). Organisationskulturals Einflussgröße der Export Performance. Wiesbaden: Deutscher Universitäts Verlag.

Lumpkin, G.T., \& Sloat C. (2001). Do family firms an entrepreneurial orientation? Flontiers of entrepreneurship research, 26 (5), 347-366.

Miles, J. \& Shevlin, M. (2003). Structural equation modelling: Navigating spaghetti junction. Psychologist, 16, 639-641.

Mintgberg H. (1998). structure in fives; designing effective organizations. Pp.312. Englewood cliffs, NJ: Prentice - Hall.

Mossete, G.N. (2013). Social entrepreneurial leadership. Career Development International 4 (3): 140-145. 
Nadler, D. A. (1998). Champions of change: How CEOs and their companies are mastering the skills of radical change. San Francisco: Jossey-Bass.

Ndungu, S. I. (2014). Moderating Role of entrepreneurial orientation between security management and firm performance. Unpublished PhD. Thesis. Nairobi. Jomo Kenyatta University \& Technology.

Ogbonna, E. \& Harris, L. (2000). Leadership style, organizational culture and performance: Empirical evidence from U.K companies, international Journal of human resource management; 11(4), 706788.

Olsen, B. (2008). How reasons for entry into the profession illuminate teacher identity development. Teacher Education Quarterly, 35(3).

Ongori, H (2009). Managing behind the scenes: A view point on employee empowerment. African Journal of Business Management, 3 (1), 009-015.

Rauch, A., Wiklund, J., Lumpkin, G.T. and Frese, M. (2009). EO and Business Performance: An Assessment of Past Research and Suggestions for the Future. Entrepreneurship Theory and Practice. 33, 761-787.

Richard, O.C., Barnett T., Dwyer. S. and Chadwick, K. (2004). Culture diversity in management firm performance and moderating role of entrepreneurial orientation dimensions. Academy of management, Journal, 47 (2): 255-266.

Schneider, B., Brief, A. P., \& Guzzo, R. A. (1996). Creating a climate and culture for sustainable organizational change. Organizational Dynamics, 24(4), 7-19.

Senge, P. (1990). The fifth discipline: The art and practice of the learning organization. New York: Doubleday/Currency.

Shihab, M. S., Wismiarsi, T., \& Sine, K. (2011). Relationship between organizational culture and entrepreneurial orientation: Indonesian SMEs context. International Proceedings of Economics Development \& Research, 24, 93.

Singh, S. K. (2011). Organizational Innovation as Competitive Advantage during Global Recession. The Indian Journal of Industrial Relations, 46(4).165-185.

Stalk, G. J. (1998). The time paradigm. Forbes (ASAP Supplement), 213-14.

Swanson, S. \& Davis, J. C. (2003). The Relationship of Differential Loci with Perceived Quality and Behavioral Intentions. Journal of Services Marketing, 17 (2), 202-219.

Tidor, A., Gelmereanu, C., Baru, P., \& Morar, L. (2012). Diagnosing Organizational Culture for SMEs Performance. Procedia Econonomics and Finance, 710-715.

Wales, W. J., Gupta V. K., \& Mousa FT (2013a). Empirical research on entrepreneurial orientation: An assessment and suggestions for future research. International Small Business Journal 31(4): 357-383.

Wandongo, B., Odhuno, E., \& Kambona, O. (2010). Managerial role and choice of performance measure in the Kenyan five star hotels using a cross- sectional correlation design. Managing leisure, 15(11), 17-31.

Wei, L., Liu J., \& Herndon, N.C. (2011). SHRM and Product Innovation: Testing the moderating effects of organizational culture and structure in Chinese Firms. The International Journal of Human Resource Management, 22 (1), 19-33.

Wiklund, J., \& Shepherd, D.A. (2003). Knowledge-based resources, entrepreneurial orientation and the performance of small and medium sized businesses. Strategic Management Journal 24, $1307-$ 1314.

Wilkins, A.L., \& Ouchin W.G. (1983). Efficient cultures; exploring the relationship between culture and organizational performance Administrative science Quarterly, 28 (3): 468 - 481. 